\title{
Aktivitas Belajar dan Perilaku Kerja Inovatif pada Masa Pandemi Dimediasi oleh Efikasi-Diri Inovasi
}

\section{Learning Activities and Innovative Work Behavior during Pandemic Mediated by Innovative Self-Efficacy}

\author{
Dhea Rizky Ardini ${ }^{1}$, Arum Etikariena ${ }^{2}$ \\ ${ }^{1,2}$ Fakultas Psikologi, Universitas Indonesia
}

\begin{abstract}
Innovative work behavior has been studied as a useful thing for the company's sustainability during the Covid-19 pandemic. However, changes in various aspects of work environment due to the outbreak pose challenges for employees to display innovative behavior. It is suspected that individual belief in innovation can help employees to provide innovative behavior. This study aimed to examine the role of innovative self-efficacy as a mediator in the relationship between formal and informal learning activities on employees' innovative work behavior. The respondents are employees with age range 24-44 years who worked in the Jakarta Metropolitan area with minimum 1 year of service period and had at least a bachelor degree. The scales used were Formal Learning Activity Scale, Informal Learning Activity Scale, Innovative Self-Efficacy Scale, and Innovative Work Behavior Scale. A quantitative study was conducted on 165 respondents using the accidental sampling method. This research method used a survey method by distributing online questionnaires. For data processing using mediation regression analysis with SPSS 25 PROCESS. The results of data analysis showed that innovation self-efficacy partially mediates the relationship between formal and informal learning activities and innovative work behavior. The results of this study have positive implications for employees, supervisors, and companies.
\end{abstract}

Keywords: covid-19; innovative self-efficacy; innovative work behavior; learning activity

Abstrak. Perilaku kerja inovatif telah diteliti sebagai salah satu hal yang berguna bagi keberlangsungan perusahaan di masa pandemi Covid-19. Namun, perubahan pada berbagai aspek dalam lingkungan kerja akibat penyebaran Covid-19 menimbulkan tantangan bagi karyawan untuk menampilkan perilaku inovatif. Diduga bahwa keyakinan individu untuk berinovasi dapat membantu karyawan untuk dapat konsisten memberikan performa terbaiknya dengan menampilkan perilaku inovatif di masa pandemi Covid-19. Penelitian ini bertujuan untuk melihat peran efikasi-diri inovasi sebagai variabel mediator dalam hubungan antara aktivitas belajar formal maupun informal terhadap perilaku kerja inovatif karyawan. Responden penelitian ini merupakan karyawan dengan rentang usia 24-44 tahun yang bekerja di area Jabodetabek dengan masa kerja minimal 1 tahun dan pendidikan terakhir minimal S-1. Skala yang digunakan adalah Skala Aktivitas Belajar Formal, Skala Aktivitas Belajar Informal, Skala Efikasi-Diri Inovasi, dan Skala Perilaku Kerja Inovatif. Studi kuantitatif dilakukan terhadap 165 responden menggunakan metode accidental sampling. Metode penelitian ini menggunakan metode survei dengan menyebarkan kuesioner daring. Untuk pengolahan data menggunakan analisis regresi mediasi dengan aplikasi statistik SPSS 25 PROCESS. Hasil analisis data menunjukkan bahwa efikasi diri inovasi memediasi sebagian hubungan antara aktivitas belajar formal dan informal dengan perilaku kerja inovatif. Hasil penelitian ini memberikan implikasi positif kepada karyawan, penyelia, maupun perusahaan.

Kata kunci: aktivitas belajar; covid-19; efikasi-diri inovasi; perilaku kerja inovatif

Perilaku inovatif karyawan di masa pandemi Covid-19 telah diteliti menjadi salah satu hal yang berguna bagi keberlangsungan perusahaan (Darwish et al., 2020). Manfaat 
perilaku inovatif karyawan lainnya juga telah banyak diteliti sebelumnya (Janssen, 2000; Lecat et al., 2018). Bagi organisasi, manfaat yang bisa dirasakan contohnya adalah peningkatan performa organisasi (Shanker et al., 2017). Bagi karyawan, perilaku kerja inovatif membantu perbaikan kinerja hingga penurunan stres (Janssen et al., 2004). Maka, di situasi pandemi seperti ini, agar karyawan tetap bisa produktif dan menampilkan performa yang baik karyawan perlu tetap menampilkan perilaku inovatif. Hal tersebut disebabkan karena penyebaran virus penyebab Covid-19 memberikan dampak terhadap cara individu bekerja (Organisation for Economic Co-operation and Development [OECD], 2020). Banyak karyawan menghadapi tantangan baru, yaitu secara tiba-tiba menghadapi situasi kerja yang serba daring. Perubahan tersebut bermula dari terbitnya Peraturan Pemerintah Nomor 21 Tahun 2020 mengenai Pembatasan Sosial Berskala Besar (PSBB). Peraturan tersebut menganjurkan perusahaan untuk mengubah cara kerjanya dari tatap muka menjadi sistem kerja di rumah. Tidak banyak perusahaan maupun karyawan yang memiliki pengalaman bekerja jarak jauh (Schmidt, 2000), sehingga perilaku inovatif karyawan di masa pandemi diharapkan dapat membantu karyawan maupun perusahaan untuk cepat beradaptasi dalam situasi yang serba tidak pasti ini.

Definisi perilaku kerja inovatif mengacu pada perilaku individu dalam menampilkan, mempromosikan, dan mengimplementasikan ide-ide baru dalam pekerjaannya (Scott \& Bruce, 1994). Perilaku kerja inovatif merupakan konstruk yang dinamis sebagai gabungan dari adanya aktivitas fisik maupun kognitif yang dilakukan karyawan dalam konteks pekerjaan dalam rangka menyelesaikan tugas secara mandiri maupun kelompok (Messmann \& Mulder, 2012). Beberapa manfaat dari perilaku kerja inovatif diantaranya adalah membuat pekerjaan karyawan lebih efisien (Lecat et al., 2018), meningkatkan kemampuan adaptasi dengan pekerjaannya dan pengembangan diri yang baik (Janssen et al., 2004). Manfaat tersebut tentunya relevan dengan situasi pandemi, di mana karyawan dituntut untuk beradaptasi dengan cara kerja yang berubah secara tibatiba, namun tetap perlu menampilkan performa yang baik.

Terdapat beberapa faktor yang dapat memengaruhi perilaku kerja inovasi karyawan, diantaranya adalah aktivitas belajar (Lecat et al., 2018; Olsen, 2016) dan efikasidiri yang spesifik pada kegiatan inovasi atau yang disebut dengan efikasi-diri inovasi (Dörner, 2012; Gerber et al., 2012). Selain itu, usia (Etikariena, 2018; Hernaus et al., 2019), latar belakang pendidikan (Etikariena, 2018; Østergaard et al., 2011), dan masa kerja (Etikariena, 2018; Woods et al., 2017) juga memengaruhi perilaku kerja inovatif.

Di masa yang serba tidak pasti seperti masa pandemi Covid-19 ini, aktivitas belajar dinilai penting untuk selalu dilakukan karena dinilai sebagai hal utama yang mendasari seseorang berperilaku inovatif di tempat kerja (Froehlich et al., 2019; Lecat et al., 2018; Messmann \& Mulder, 2011). Selain itu, aktivitas belajar karyawan memberikan manfaat bagi individu maupun organisasi.

Bagi individu, seseorang yang mampu mengombinasikan ilmu yang dimiliki dengan ilmu baru lebih siap untuk perubahan transformasional yang berguna bagi 
perusahaan (London, 2011). Bagi perusahaan, mengelola bakat-bakat karyawan dapat membantu perusahaan melewati turbulensi pasar, menjaga keterlibatan karyawan, dan menjadi sukses pada masa yang akan datang (Robison, 2009). Chanana dan Sangeeta (2020) menyatakan bahwa salah satu cara yang bisa dilakukan oleh perusahaan untuk mengelola bakat karyawan di masa pandemi Covid-19 adalah dengan mendukung aktivitas belajar karyawan. Karyawan yang rutin mengembangkan kompetensi baru dalam pekerjaan cenderung melihat kemungkinan baru dalam melakukan dan ingin mencoba hal baru (Gerken, 2016).

Penelitian sebelumnya menyatakan bahwa konstruk aktivitas belajar formal dan informal tidak berhubungan secara signifikan, namun saling mendukung (Van Der Heijden et al., 2009). Atas dasar itu, aktivitas belajar formal dan informal dianggap sebagai konstruk yang berbeda namun saling mendukung. Untuk itu, definisi aktivitas belajar dibagi menjadi 2, yaitu aktivitas belajar formal dan aktivitas belajar informal.

Aktivitas belajar formal mengacu pada kegiatan terencana yang bertujuan untuk memberikan dukungan kepada karyawan dalam memperoleh keterampilan dan pengetahuan yang relevan dengan pekerjaan mereka (Lecat et al., 2018). Contohnya bisa berupa seminar, konferensi, pelatihan, hingga kegiatan lainnya yang dilakukan di dalam kelas (Cerasoli et al., 2018; Kyndt \& Baert, 2013). Jenjang pendidikan juga termasuk dalam aktivitas belajar formal di luar konteks organisasi (Cerasoli et al., 2018). Sedangkan aktivitas belajar informal merupakan aktivitas belajar yang dilakukan karyawan kepada karyawan lainnya mengenai tantangan dan keberhasilan yang mereka hadapi di tempat kerja berupa kegiatan seperti mencari umpan balik mengenai pekerjaan, meminta bantuan rekan/sejawat, hingga mencari informasi (Froehlich et al., 2017). Contoh kegiatannya berupa inisiatif untuk mencari umpan balik mengenai pekerjaan, meminta bantuan rekan/sejawat, hingga mencari informasi (Cerasoli et al., 2018b; Froehlich et al., 2017).

Dalam sebuah penelitian dikatakan bahwa aktivitas belajar informal secara positif memengaruhi perilaku kerja inovatif, sedangkan aktivitas belajar formal tidak memiliki pengaruh terhadap perilaku inovatif karyawan (Bos-Nehles \& Veenendaal, 2019; Lecat et al., 2018). Namun, studi lain menyebutkan bahwa aktivitas belajar formal mampu memperbaiki perilaku kerja inovatif (Azevedo \& Shane, 2019), sedangkan aktivitas belajar informal tidak berkorelasi signifkan terhadap aktivitas belajar informal (Coetzer et al., 2019). Hasil penelitian antara aktivitas belajar dengan perilaku kerja inovatif masih belum konsisten, sehingga masih membuka ruang untuk eksplorasi lebih dalam. Untuk itu, muncul sebuah pertanyaan apakah diperlukan variabel mediator untuk melihat pengaruh tidak langsung untuk mendefinisikan hubungan antara aktivitas belajar dengan perilaku kerja inovatif.

Dalam teori pembelajaran sosial, aktivitas belajar merupakan proses kognitif (Bandura, 1977b) dan memungkinkan individu untuk mendapat pengalaman baru, kesempatan pencapaian kerja, dan merasakan gairah emosional (Gerber et al., 2012). 
Ketiga hal tersebut membangun keyakinan seseorang akan kemampuannya untuk mengeksekusi suatu tindakan demi menghasilkan suatu pencapaian tertentu atau yang disebut dengan efikasi-diri (Bandura, 1997).

Efikasi-diri seseorang dapat menentukan bagaimana individu berpikir mengenai kemampuan dirinya sehingga memainkan peran dalam memengaruhi motivasi seseorang untuk berperilaku (Bandura, 1986). Untuk mengukur efikasi-diri seseorang, sebaiknya harus disesuaikan dengan domain fungsi tertentu yang menjadi objek perhatian (Bandura, 2006). Maka, efikasi-diri perlu dilihat lebih spesifik pada suatu tugas yang dikerjakan individu atau objek yang ingin diukur agar lebih relevan dengan situasi dan kondisi yang ingin diteliti. Dalam penelitian ini, perilaku inovatif karyawan menjadi fokus utama karena banyak perusahaan yang mengubah cara kerjanya secara tiba-tiba akibat pandemi Covid-19. Karyawan dituntut untuk melakukan inovasi agar tetap produktif dan menampilkan performa yang baik. Oleh sebab itu, keyakinan karyawan untuk berinovasi di masa pandemi Covid-19 menjadi hal yang menarik untuk diteliti.

Efikasi-diri inovasi didefinisikan sebagai keyakinan seseorang akan kemampuannya untuk membuat hasil yang inovatif (Dörner, 2012). Efikasi-diri inovasi merupakan konstruk yang masih tergolong baru sehingga masih sangat mungkin untuk dieksplorasi lebih dalam. Selain itu, efikasi-diri dirasa perlu diteliti lebih lanjut karena keyakinan karyawan untuk menyelesaikan tugas akan menghasilkan kinerja yang baik dan memperlihatkan perilaku inovatif yang baik (Bandura \& Cervone, 1986; Gist \& Mitchell, 1992; Hsiao et al., 2011). Tidak hanya bermanfaat ada level individu, efikasi-diri inovasi dinilai dapat memberikan manfaat bagi organisasi karena dapat mendorong munculnya perilaku kerja inovatif (Dörner, 2012).

Efikasi-diri inovasi mendorong individu untuk menampilkan perilaku inovatif di tempat kerja (Dörner, 2012). Individu yang tidak memiliki keyakinan akan kemampuannya untuk berinovasi akan sulit untuk menampilkan perilaku inovatif di tempat kerja. Proses kognitif yang terjadi dari aktivitas belajar formal maupun informal menimbulkan keyakinan seseorang akan kemampuannya untuk berinovasi sehingga mendorong individu untuk menampilkan perilaku inovatif di tempat kerja. Alasannya, pengalaman belajar individu, meningkatnya pemahaman akan suatu bidang keahlian, hingga pengalaman keberhasilan menyelesaikan suatu tugas dapat menambah keyakinan seseorang untuk berinovasi. Seiring meningkatnya keyakinan individu untuk berinovasi menimbulkan dorongan untuk berani memulai melakukan kegiatan yang inovatif dalam pekerjaannya. Dengan demikian, efikasi-diri inovasi diprediksi memiliki pengaruh tidak langsung pada hubungan antara aktivitas belajar dengan perilaku kerja inovatif. Untuk itu, dibuat model teoretik sebagai berikut. 


\section{Gambar 1.}

Model Teoretis 1

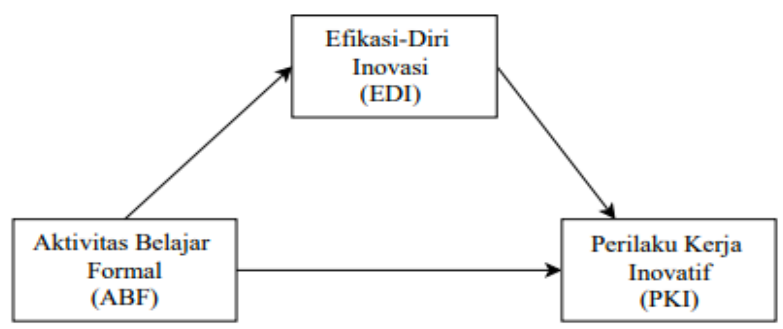

\section{Gambar 2.}

Model Teoretis 2

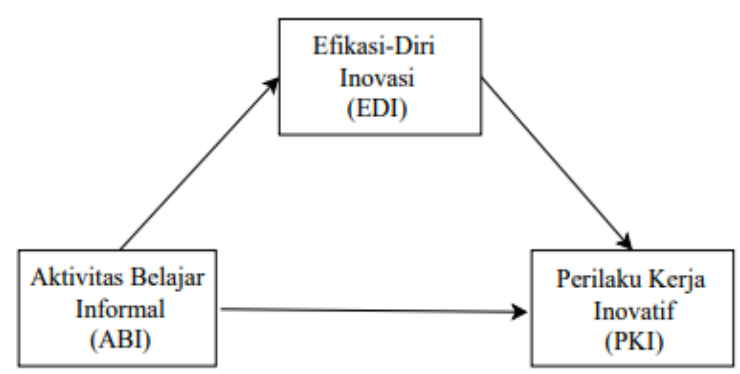

Berdasarkan penjabaran di atas, dibuat hipotesis sebagai berikut.

H1a: Efikasi-diri inovasi memediasi hubungan antara aktivitas belajar formal terhadap perilaku kerja inovatif. Artinya, efikasi-diri inovasi akan berdampak pada hubungan antara aktivitas belajar formal yang dilakukan karyawan dengan perilaku kerja inovatif di tempat kerja.

H1b: Efikasi-diri inovasi memediasi hubungan aktivitas belajar informal terhadap perilaku kerja inovatif. Artinya, efikasi-diri inovasi akan berdampak pada hubungan antara aktivitas belajar informal yang dilakukan karyawan terhadap kerja inovatif di tempat kerja.

\section{Metode}

Penelitian ini telah lolos tahap kaji etika penelitian berdasarkan Surat Keterangan Nomor 920/FPsi.Komite Etik/PDP.04.00/2020 yang dikaji oleh Komite Etika Penelitian Fakultas Psikologi Universitas Indonesia. Penelitian ini merupakan penelitian kuantitatif dengan tipe korelasional karena bertujuan untuk melihat hubungan antar variabel (Kumar, 2011). Metode yang digunakan untuk pengambilan data adalah survei dengan structured selfcompleted questionnaire, sehingga dapat diisi sendiri oleh responden sesuai dengan 
keadaan responden di mana saja dan kapan saja (Clark-Carter, 2019). Metode tersebut dipilih atas pertimbangan bahwa responden lebih memahami aktivitas dan diri responden daripada orang lain. Kuesioner dibuat dalam bentuk online melalui platform Google untuk menghindari kontak langsung dengan responden sesuai dengan anjuran PSBB.

Teknik sampling yang digunakan adalah non-probability sampling (Gravetter \& Forzano, 2012) dengan cara accidental sampling. Berdasarkan kalkulasi dengan alat bantu $G^{*}$ power, untuk mendapatkan kekuatan statistik sebesar $95 \%$ pada analisis statistik regresi dengan effect size medium $\left(f^{2}=0,30\right)$ (Cohen, 1988), pengujian 1 arah $(\alpha$-level $=0,05)$, diperlukan sampel sebanyak minimal 138 orang.

Terdapat 4 kriteria partisipan yang dicari, yaitu karyawan/karyawati yang bekerja di area Jabodetabek, rentang usia $24-44$ tahun, masa kerja minimal 1 tahun di tempat bekerja saat ini, dan pendidikan terakhir minimal S-1. Fokus penelitian hanya di area Jabodetabek karena Provinsi DKI Jakarta mendapatkan predikat provinsi terinovatif berdasarkan indeks inovasi daerah pada tahun 2020 lalu (Wahyudi, 2020) dan wilayah Bogor, Depok, Tangerang dan Bekasi masih dalam kawasan metropolitan Jakarta berdasarkan Perpres No. 54 tahun 2008.

Alat ukur yang digunakan untuk mengukur aktivitas belajar terdiri dari 2 alat ukur, yaitu Skala Aktivitas Belajar Formal (Lecat et al., 2018) dan Skala Aktivitas Belajar Informal (Froehlich et al., 2017). Skala Perilaku Kerja Inovatif menggunakan skala yang disusun oleh Janssen (2000) dan telah diterjemahkan ke dalam Bahasa Indonesia oleh Etikariena \& Muluk (2014). Terakhir, Skala Efikasi-Diri Inovasi digunakan skala yang disusun oleh Dörner (2012). Untuk Skala Aktivitas Belajar Formal, Skala Aktivitas Belajar Informal, dan Skala Efikasi-Diri Inovasi diterjemahkan dari Bahasa Inggris ke Bahasa Indonesia dengan mengadopsi metode back translate (Sousa \& Rojjanasrirat, 2011) dan skala-skala tersebut kemudian diujicobakan kepada responden dengan kriteria yang sama dengan target penelitian untuk melihat reliabilitas dan validitas alat ukur yang telah diterjemahkan. Berdasarkan hasil uji coba alat ukur, hasil koefisien korelasi Skala Aktivitas Belajar Formal dikatakan valid pada taraf signifikansi 1\% dengan koefisien reliabilitas 0,76. Untuk Skala Aktivitas Belajar Informal, seluruh butir skala ini dinyatakan valid pada taraf signifikansi 5\% dengan konsistensi internal keseluruhan butir yang sudah diterjemahkan tergolong cukup baik $(\alpha=0,72)$. Selanjutnya, untuk seluruh butir pada Skala Perilaku Kerja Inovatif dikatakan valid pada taraf signifikansi 5\% dengan nilai koefisien internal 0,78. Terakhir, butir-butir pada Skala Efikasi-Diri Inovasi dinyatakan valid pada taraf signifikansi $5 \%$ dengan konsistensi internal yang juga cukup baik $(\alpha=0,77$, $\mathrm{N}=34$ ). Mengacu pada Nunnally dan Bernstein (1994) suatu alat ukur dikatakan reliabel jika koefisien reliabilitas minimal 0,7. Maka, skala-skala yang telah diterjemahkan ini cukup reliabel untuk digunakan.

Data yang terkumpul diolah secara kolektif menggunakan program SPSS untuk iOS versi 25. Pengolahan data dimulai dengan analisis deskriptif dan analisis korelasional 
untuk melihat hubungan confounding variabel demografis dengan variabel terikat. Selanjutnya, untuk pengujian hipotesis menggunakan SPSS PROCESS versi 3.5 Model 4 yang dikembangkan oleh (Hayes, 2018). Pengumpulan data dilakukan selama 11 hari dan terkumpul 195 responden. Namun, hanya 165 respons yang memenuhi kriteria dan datanya laik olah. Sisanya sebanyak 30 respons tidak bisa diolah karena tidak memenuhi kriteria penelitian seperti usia, domisili tempat bekerja, masa kerja, dan jenjang pendidikan.

\section{Hasil}

Sebagai gambaran umum, responden dalam penelitian ini seluruhnya merupakan karyawan (40\%) dan karyawati $(60 \%)$ dengan rentang usia 24 - 44 tahun $(100 \%)$ dan seluruhnya bekerja di area Jabodetabek. Latar belakang pendidikan mayoritas responden adalah S1 (89,7\%) dan pascasarjana jenjang S2 hingga S3 (10,4\%). Responden-responden tersebut mayoritas telah bekerja selama 3 - 10 tahun (47,3\%). Mayoritas responden bekerja pada sektor jasa (63,8 \%). Sisanya bekerja di instansi pemerintahan $(10,3 \%)$, manufaktur $(3,6 \%)$, perdagangan $(3,6 \%)$, ekstraktif $(2,4 \%)$ dan sektor lainnya yang tidak dapat digolongkan karena data yang kurang lengkap (16,4\%).

\section{Tabel 1}

Hasil Analisis Korelasional Antar Variabel

\begin{tabular}{|c|c|c|c|c|c|c|c|c|c|c|}
\hline & $\mathbf{M}$ & SD & 1 & 2 & 3 & 4 & 5 & 6 & 7 & 8 \\
\hline Usia & 31,16 & 5,55 & 1 & & & & & & & \\
\hline Jenis kelamin & & &,- 01 & 1 & & & & & & \\
\hline $\begin{array}{l}\text { Pendidikan } \\
\text { terakhir }\end{array}$ & & & ,06 & ,03 & 1 & & & & & \\
\hline Masa kerja & 1,92 & 0,72 &, $72^{*}$ &,- 04 & ,04 & 1 & & & & \\
\hline $\mathrm{ABI}$ & 20 & 6,7 &, $19^{*}$ & ,09 &, $18^{*}$ &, $16^{*}$ & 1 & & & \\
\hline $\mathrm{ABF}$ & 12,6 & 3,12 & ,06 &, $18^{*}$ & ,07 & 13 &, $37^{*}$ & 1 & & \\
\hline EDI & 18 & 6 &,- 11 & ,02 & ,05 &,- 08 & $20^{*}$ &, $31^{*}$ & 1 & \\
\hline PKI & 22,5 & 7,5 &,- 06 & ,03 & ,07 &,- 01 & $25^{*}$ & $41^{*}$ &, $57^{*}$ & 1 \\
\hline
\end{tabular}

Catatan:

ABI: Aktivitas Belajar Informal, ABF: Aktivitas Belajar Formal, EDI: Efikasi Diri Inovasi, PKI: Perilaku Kerja Inovatif

*) Korelasi signifikan pada level 0,05 (2-arah) 
Analisis dimulai dengan melihat apakah terdapat hubungan positif dan signifikan antara variabel-variabel demografis dengan perilaku kerja inovatif. Dengan melihat hubungan antar variabel, dapat dilakukan kontrol terhadap variabel demografis yang nantinya akan disertakan dalam analisis regresi. Variabel demografis yang disertakan dalam penelitian ini antara lain adalah usia, jenis kelamin, pendidikan terakhir, dan masa kerja. Hasilnya memerlihatkan bahwa variabel jenis kelamin, pendidikan terakhir, usia dan masa kerja berkorelasi tidak signifikan terhadap perilaku kerja inovatif. Untuk itu, variabel usia, jenis kelamin, pendidikan terakhir, dan masa kerja tidak disertakan dalam analisis regresi selanjutnya.

Analisis regresi mediasi dilakukan untuk menguji hipotesis yang berbunyi efikasidiri inovasi memediasi hubungan aktivitas belajar formal dengan perilaku kerja inovatif. Hasilnya menunjukkan bahwa efikasi-diri inovasi memediasi sebagian hubungan antara aktivitas belajar formal dengan perilaku kerja inovatif dengan efek tidak langsung sebesar $0,11(p<0,05)$ dan efek langsung sebesar 0,14 $(p<0,05)$ (koefisien adalah standardized).

\section{Tabel 2}

Pengaruh Aktivitas Belajar Formal dan Efikasi-Diri Inovasi Terhadap Perilaku Kerja Inovatif

\begin{tabular}{|c|c|c|c|c|c|c|c|c|}
\hline \multirow[b]{3}{*}{ Antesenden } & & \multicolumn{4}{|c|}{ Consequent } & & & \\
\hline & & \multicolumn{3}{|c|}{$M($ EDI) } & & \multicolumn{3}{|c|}{$Y(\mathbf{P K I})$} \\
\hline & & Koefisien & $S E$ & $p$ & & Koefisien & $S E$ & $p$ \\
\hline$X(\mathrm{ABF})$ & $a$ & 0,20 & 0,07 & 0,01 & $c^{\prime}$ & 0,14 & 0,12 & 0,04 \\
\hline$M(\mathrm{EDI})$ & & - & - & - & $b$ & 0,54 & 0,11 & 0,00 \\
\hline \multirow[t]{3}{*}{ Konstan } & $i_{M}$ & 33,44 & 0,67 & 0,00 & $i r$ & 3,26 & 3,92 & 0,41 \\
\hline & & \multicolumn{3}{|c|}{$\mathrm{R}^{2}=0,04$} & & \multicolumn{3}{|c|}{$\mathrm{R}^{2}=0,34$} \\
\hline & & \multicolumn{3}{|c|}{$F(1,163)=6,97, p=0,01$} & & \multicolumn{3}{|c|}{$F(2,162)=41,28, p=0,00$} \\
\hline
\end{tabular}

Keterangan: $\mathrm{a}^{*} \mathrm{~b}=$ indirect effect $=0,11, c=$ total effect, $c^{\prime}=$ direct effect. Koefisien yang ditampilkan adalah standardize.

Dari hasil analisis statistik pada Tabel 2 dapat disimpulkan bahwa hipotesis 1a diterima, yaitu efikasi- diri inovasi memediasi sebagian hubungan antara aktivitas belajar formal terhadap perilaku kerja inovatif karyawan. Efek tidak langsung lebih kecil dari efek langsung. Hal ini mengindikasikan bahwa peran proses belajar formal lebih besar daripada efikasi-diri inovasi dan terdapat faktor lain yang memengaruhi perilaku kerja inovatif selain efikasi- diri inovasi. Untuk itu, mediasi terjadi secara parsial dalam hubungan antara aktivitas belajar formal dengan perilaku kerja inovatif. 
Selanjutnya, analisis dilakukan untuk menguji hipotesis yang berbunyi apakah efikasi-diri inovasi memediasi hubungan aktivitas belajar informal dengan perilaku kerja inovatif. Hasilnya menunjukkan bahwa efikasi-diri inovasi memediasi sebagian hubungan antara aktivitas belajar informal dengan perilaku kerja inovatif dengan efek tidak langsung sebesar 0,15 ( $p<0,05)$ dan efek langsung sebesar 0,25 $(p<0,05)$ (koefisien adalah standardized).

\section{Tabel 3}

Pengaruh Aktivitas Belajar Informal dan Efikasi-Diri Inovasi Terhadap Perilaku Kerja Inovatif

\begin{tabular}{|c|c|c|c|c|c|c|c|c|}
\hline \multirow[b]{3}{*}{ Antesenden } & & \multicolumn{4}{|c|}{ Consequent } & & & \\
\hline & & \multicolumn{3}{|c|}{$M$ (EDI) } & & \multicolumn{3}{|c|}{$Y($ PKI) } \\
\hline & & Koefisien & $S E$ & $p$ & & Koefisien & $S E$ & $p$ \\
\hline$X(\mathrm{ABI})$ & $a$ & 0,31 & 0,07 & 0,00 & $c^{\prime}$ & 0,25 & 0,10 & 0,00 \\
\hline$M(\mathrm{EDI})$ & & - & - & - & $b$ & 0,49 & 0,11 & 0,00 \\
\hline \multirow[t]{3}{*}{ Konstan } & $i_{M}$ & 23,54 & 2,71 & 0,00 & $i_{Y}$ & $-7,94$ & 4,75 & 0,10 \\
\hline & & \multicolumn{3}{|c|}{$\mathrm{R}^{2}=0,10$} & & \multicolumn{3}{|c|}{$\mathrm{R}^{2}=0,38$} \\
\hline & & \multicolumn{3}{|c|}{$F(1,163)=18,95, p=0,000$} & & \multicolumn{3}{|c|}{$F(2,162)=49,41, p=0,00$} \\
\hline
\end{tabular}

Keterangan: $\mathrm{a}^{*} \mathrm{~b}=$ indirect effect $=0,15, c=$ total effect, $c^{\prime}=$ direct effect. Koefisien yang ditampilkan adalah standardize.

Berdasarkan hasil analisis statistik pada Tabel 3, dapat disimpulkan bahwa hipotesis $1 \mathrm{~b}$ diterima, yaitu efikasi-diri inovasi memediasi hubungan antara aktivitas belajar informal terhadap perilaku kerja inovatif karyawan secara parsial. Efek tidak langsung lebih kecil dari efek langsung, sehingga peran proses belajar informal lebih besar daripada efikasi-diri inovasi dan terdapat faktor lain yang memengaruhi perilaku kerja inovatif selain efikasi-diri inovasi. Oleh karena itu, peran mediator dalam hubungan antara aktivitas belajar informal terhadap perilaku kerja inovatif bersifat parsial. 


\section{Tabel 4}

Gambaran Skor Responden

\begin{tabular}{lcccccccc} 
& \multicolumn{2}{c}{$\begin{array}{c}\text { Perilaku Kerja } \\
\text { Inovatif }\end{array}$} & \multicolumn{2}{c}{$\begin{array}{c}\text { Aktivitas Belajar } \\
\text { Fomal }\end{array}$} & $\begin{array}{c}\text { Aktivitas Belajar } \\
\text { Informal }\end{array}$ & \multicolumn{2}{c}{$\begin{array}{c}\text { Efikasi-Diri } \\
\text { Inovasi }\end{array}$} \\
\hline Tinggi & 151 & 91,5 & 23 & 13,9 & 163 & 98,8 & 164 & 99,4 \\
\hline Rendah & 14 & 8,5 & 142 & 86,1 & 2 & 1,2 & 1 & 0,6 \\
\hline Total & $\mathbf{1 6 5}$ & $\mathbf{1 0 0}$ & $\mathbf{1 6 5}$ & $\mathbf{1 0 0}$ & $\mathbf{1 6 5}$ & $\mathbf{1 0 0}$ & $\mathbf{1 6 5}$ & $\mathbf{1 0 0}$ \\
\hline
\end{tabular}

Untuk mendapatkan gambaran responden secara komprehensif, dilakukan kategorisasi berdasarkan skor alat ukur dengan referensi kriteria (Kaplan \& Saccuzzo, 2013) menggunakan statistik hipotetik (Azwar, 2012). Nilai rata-rata (mean) skala digunakan sebagai dasar penentuan. Kategorisasi pada setiap variabel digolongkan menjadi dua, yaitu tinggi dan rendah. Hasil dapat dilihat pada tabel 4 yang menunjukkan bahwa mayoritas responden pada masa pandemi Covid-19 merasa yakin untuk berinovasi dan menampilkan perilaku inovatif saat bekerja. Uniknya, mayoritas responden lebih banyak melakukan aktivitas belajar informal daripada aktivitas belajar formal.

\section{Diskusi}

Hasil penelitian memperlihatkan bahwa efikasi-diri inovasi memediasi sebagian hubungan antara aktivitas belajar formal dengan perilaku kerja inovatif. Artinya, ada atau tidak adanya efikasi-diri inovasi akan tetap dapat memberikan dampak terhadap perilaku kerja inovatif. Hal ini bisa terjadi karena aktivitas belajar formal merupakan suatu pengalaman individu yang bisa langsung diimplementasikan untuk menyelesaikan tugas (Schar, et al., 2017), sehingga aktivitas belajar formal memengaruhi langsung perilaku kerja inovatif (Azevedo \& Shane, 2019; Olsen, 2016). Mediasi parsial juga terjadi karena terdapat faktor lain yang memengaruhi perilaku kerja inovatif selain efikasi- diri inovasi. Mengacu pada hasil analisis korelasional, usia, masa kerja, dan pendidikan terakhir berhubungan positif dan signifikan terhadap aktivitas belajar formal. Variabel-variabel demografis tersebut diduga memengaruhi perilaku kerja inovatif (Van Der Heijden, et al., 2009) meski telah mengontrol variabel efikasi-diri inovasi.

Pembahasan selanjutnya yaitu efikasi-diri inovasi memediasi sebagian hubungan antara aktivitas belajar informal dengan perilaku kerja inovatif secara parsial. Artinya, ada atau tidak adanya efikasi-diri inovasi dalam hubungan antara aktivitas belajar informal akan tetap memberikan dampak terhadap perilaku kerja inovatif. Seperti halnya aktivitas belajar formal, aktivitas belajar yang didapatkan dari orang lain atau inisiatif 
individu memengaruhi perilaku inovatif yang ditampilkan (Gerber et al., 2012). Maka, kegiatan belajar informal tersebut diduga menjadi penyebab mengapa aktivitas belajar informal masih memiliki pengaruh langsung meski telah melibatkan efikasi-diri inovasi. Mediasi parsial juga terjadi karena adanya faktor lain yang memengaruhi perilaku kerja inovatif selain efikasi-diri inovasi. Faktor jenis kelamin (Van Der Heijden et al., 2009) diduga memengaruhi hubungan aktivitas belajar informal terhadap perilaku kerja inovatif. Hal tersebut diperkuat dengan hasil analisis korelasional yang berhubungan positif dan signifikan terhadap aktivitas belajar informal.

Peran efikasi-diri inovasi sebagai mediator memperkuat hubungan antara aktivitas belajar formal maupun informal dengan perilaku kerja inovatif karena keyakinan seseorang terhadap kemampuan diri merupakan prosekutor dari perilaku individu (Bandura, 1977a). Meningkatnya keyakinan karyawan untuk menyelesaikan suatu tugas akan memperlihatkan perilaku inovatif yang baik (Bandura, 1986; Gist \& Mitchell, 1992; Hsiao, et al., 2011). Untuk itu, keyakinan seseorang akan kemampuannya berinovasi berdampak terhadap perilaku kerja inovatif.

Responden dalam penelitian ini merupakan karyawan dalam kelompok usia 24-44 tahun. Pada kelompok usia tersebut sangat mungkin untuk memiliki keyakinan untuk berinovasi yang tinggi dan menunjukkan perilaku inovatif di tempat kerja. Individu mulai meniti posisi kerjanya dan memungkinkan untuk menunjukkan diri di lingkungan kerjanya, menunjukkan sikap kerja yang baik, dan membangun relasi yang baik dengan koleganya (Etikariena, 2018). Maka, logis jika hasil skor gambaran perilaku kerja inovatif dan efikasi-diri inovasi dalam penelitian ini berada pada kategori tinggi di masa pandemi seperti ini.

Selain itu, terlihat juga selama masa pandemi Covid-19 ini, aktivitas belajar informal lebih banyak dilakukan oleh responden dibanding aktivitas belajar informal. Hal ini bisa jadi karena beberapa perusahaan telah memangkas biaya pelatihan selama masa pandemi Covid-19 (Hancock \& Schaninger, 2020; Sitanggang, 2020) sehingga berdampak pada aktivitas belajar formal karyawan. Fenomena ini bisa juga disebabkan karena aktivitas belajar informal lebih mudah dilakukan oleh siapa saja dan dapat dilakukan kapan saja dibandingkan dengan aktivitas belajar formal. Hal lainnya bisa jadi karena bunyi butir aktivitas belajar informal lebih dekat dengan kegiatan yang dilakukan oleh responden sehari-hari, sehingga responden merasa lebih bisa memosisikan dirinya pada aktivitas belajar informal. Namun, untuk mendapatkan gambaran yang lebih komprehensif mengenai hal ini, perlu ditelaah lebih dalam dari faktor individu maupun eksternal.

Penelitian ini tentunya tidak luput dari beberapa limitasi. Teknik sampling yang digunakan adalah accidental sampling, sehingga karakteristik responden yang didapat dalam penelitian ini sangat beragam. Untuk itu, penelitian mengenai aktivitas belajar formal dan informal sebaiknya dilakukan dalam satu perusahaan untuk mengontrol responden dan melihat perbandingan antar aktivitas belajar dengan lebih jelas. Kelompok 
usia sebaiknya tidak terbatas pada kelompok usia tertentu untuk memperkaya analisis. Populasi yang terbatas hanya di Jabodetabek bisa jadi kurang merepresentasikan kondisi pekerja di Indonesia, sehingga masih mungkin untuk mengambil populasi yang lebih luas. Untuk mengontrol responden, penelitian dalam konteks pandemi sebaiknya memerhatikan apakah karyawan bekerja dan belajar dari rumah, dari kantor atau campuran keduanya. Penelitian di luar konteks pandemi Covid-19 mungkin akan memberikan hasil yang berbeda sehingga dapat dipertimbangkan untuk penelitian di masa mendatang.

\section{Kesimpulan}

Penelitian ini merupakan penelitian awal mengenai peran efikasi-diri inovasi dalam hubungan antara aktivitas belajar formal dan informal dengan perilaku kerja inovatif karyawan di masa pandemi Covid-19. Hasilnya, dapat disimpulkan bahwa efikasi-diri inovasi memediasi hubungan antara aktivitas belajar formal dan informal terhadap perilaku kerja inovatif. Artinya, aktivitas belajar formal dan informal, baik secara langsung atau melalui efikasi diri inovasi, sama-sama akan berdampak perilaku kerja inovatif. Selain itu, penelitian ini mengungkapkan sebuah temuan bahwa pada masa pandemi Covid-19, karyawan lebih banyak melakukan aktivitas belajar informal daripada aktivitas belajar formal. Hal ini tentunya perlu penelitian lebih lanjut dari berbagai aspek.

\section{Saran}

Hasil penelitian menunjukkan bahwa efikasi-diri memiliki peran positif di masa pandemi Covid-19 dalam memediasi hubungan antara aktivitas belajar formal dan informal terhadap perilaku kerja inovatif. Sepanjang pengetahuan peneliti, belum banyak penelitian yang fokus meneliti mengenai peran efikasi-diri inovasi pada karyawan di Indonesia, sehingga masih banyak ruang eksplorasi mengenai konstruk tersebut. Perlu studi literatur dan penelitian lebih dalam mengenai peran efikasi-diri inovasi sebagai variabel mediator sempurna.

\section{Ucapan terima kasih}

Penelitian ini telah berhasil dipertahankan di hadapan Dewan Penguji Tesis. Untuk itu, penulis mengucapkan terima kasih kepada partisipan penelitian maupun pihak-pihak yang membantu menyukseskan proses pengumpulan data.

\section{Kontribusi penulis}

Penyusunan naskah penelitian dilakukan oleh DRA dibawah bimbingan AEH sebagai prasyarat untuk memperoleh gelar Magister Profesi Psikologi. Seluruh penulis telah membaca dan menyetujui hasil akhir dari naskah penelitian ini. 


\section{Konflik kepentingan}

Dengan ini menyatakan bahwa penulis tidak memiliki konflik kepentingan dalam penelitian, penulisan hasil penelitian, dan/atau publikasi penelitian ini.

\section{Pendanaan}

Dana yang dikeluarkan untuk penelitian ini berasal dari pendanaan pribadi penulis.

\section{Kepustakaan}

Azevedo, A., \& Shane, M. J. (2019). A new training program in developing cultural intelligence can also improve innovative work behavior and resilience: A longitudinal pilot study of graduate students and professional employees. International Journal of Management Education, 17(3), 100303. https://doi.org/10.1016/j.ijme.2019.05.004

Azwar, S. (2012). Reliabilitas dan validitas (Edisi keempat). Pustaka Pelajar.

Bandura, A. (1977a). Self-efficacy: Toward a unifying theory of behavioral change. Psychological Review, 84(2), 191-215. https://doi.org/10.1016/0146-6402(78)90002-4

Bandura, A. (1977b). Social learning theory. Diakses dari http://library.lol/main/D361C0344BEE96F7AB9D34B600C7EEE7

Bandura, A. (1986). The Explanatory and predictive scope of self-efficacy theory. Journal of Social and Clinical Psychology, 4(3), 359-373. https://doi.org/10.1521/jscp.1986.4.3.359

Bandura, A. (1997). Self-efficacy: The exercise of control. Diakses dari http://search.ebscohost.com/login.aspx?direct=true\&db=a9h\&AN=9703260522\&site $=$ ehost-live

Bandura, A. (2006). Guide for constructing self-efficacy scales. Dalam F. Pajares \& T. C. Urdan (Eds.), Self-Efficacy Beliefs of Adolescents (hal. 307-337). Diakses dari https://www.uky.edu/ eushe2/Bandura/BanduraGuide2006.pdf

Bandura, A., \& Cervone, D. (1986). Differential engagement of self-reactive influences in cognitive motivation. Organizational Behavior and Human Decision Processes, 38(1), 92-113. https://doi.org/10.1016/0749-5978(86)90028-2

Bos-nehles, A. C., \& Veenendaal, A. A. R. (2019). Perceptions of HR practices and innovative work behavior: The moderating effect of an innovative climate. The International Journal of Human Resource Management, 30(18), 2661-2683. https://doi.org/10.1080/09585192.2017.1380680.

Cerasoli, C. P., Alliger, G. M., Donsbach, J. S., Mathieu, J. E., Tannenbaum, S. I., \& Orvis, K. A. (2018). Antecedents and outcomes of informal learning behaviors: A metaanalysis. Journal of Business and Psychology, 33, 203-230. https://doi.org/10.1007/s10869-017-9492-y

Chanana, N., \& Sangeeta. (2020). Employee engagement practices during COVID-19 
lockdown. Journal of Public Affairs, (8), 1-8. https://doi.org/10.1002/pa.2508

Clark-Carter, D. (2019). Quantitative psychological research: The complete student's companion (Edisi keempat). https://doi.org/10.1111/j.2044-8317.2010.02008.x

Coetzer, A., Susomrith, P., \& Ampofo, E. T. (2020). Opportunities to participate in formal and informal vocational learning activities and work-related outcomes in small professional services businesses. Journal of Vocational Education \& Training, 72(1), 88-114. https://doi.org/10.1080/13636820.2019.1584637

Cohen, J. (1988). Statistical power analysis for the behavioral sciences (Edisi kedua). https://doi.org/10.1007/BF00544941

Darwish, S., Ahmed, U., \& Pahi, M. H. (2020). Research article innovative work behavior during covid-19 for medical representatives in the pharmaceutical industry. International Journal of Pharmaceutical Research, 12(4), 1927-1934. https://doi.org/10.31838/ijpr/2020.12.04.277

Dörner, N. (2012). Innovative work behavior: The roles of employee expectations and effects on job performance (University of St. Gallen). Diakses dari https://citeseerx.ist.psu.edu/viewdoc/download?doi=10.1.1.993.4081\&rep=rep1\&ty pe $=$ pdf

Etikariena, A. (2018). Perbedaan perilaku kerja inovatif berdasarkan karakteristik individu karyawan. Jurnal Psikologi, 17(2), 107. https://doi.org/10.14710/jp.17.2.107-118

Etikariena, A. \& Muluk, H. (2014). Hubungan antara memori organisasi dan perilaku inovatif karyawan. Makara Human Behavior Studies in Asia, 18(2), 77-88. https://doi.org/10.7454/mssh.v18i2.3463

Froehlich, D. E., Beausaert, S., \& Segers, M. (2017). Development and validation of a scale measuring approaches to work-related informal learning. International Journal of Training and Development, 21(2), 130-144. https://doi.org/10.1111/ijtd.12099

Froehlich, D. E., Segers, M., Beausaert, S., \& Kremer, M. (2019). On the relation between task-variety, social informal learning, and employability. Vocations and Learning, 12(1), 113-127. https://doi.org/10.1007/s12186-018-9212-4

Gerber, E. M., Olson, J. M., \& Komarek, R. L. D. (2012). Extracurricular design-based learning: Preparing students for careers in innovation. International Journal of Engineering Education, 28(2), 317-324. Diakses dari https://www.researchgate.net/publication/289689632_Extracurricular_DesignBased_Learning_Preparing_Students_for_Careers_in_Innovation

Gerken, M. (2016). How do employees learn at work? (University of Maastricht). Diakses dari https://www.researchgate.net/publication/305392382_How_do_employees_learn_a t_work_Understanding_informal_learning_from_others_in_different_sectors

Gist, M. E., \& Mitchell, T. R. (1992). Self-efficacy : A theoretical analysis of its determinants and malleability. The Academy of Management Review, 17(2), 183-211. 
https://doi.org/https://doi.org/10.2307/258770

Gravetter, F. J., \& Forzano, L.-A. B. (2012). Research Methods For The Behavioral Sciences 4th edition (Edisi keempat). https://doi.org/10.1017/CBO9781107415324.004

Hancock, B., \& Schaninger, B. (2020). HR says talent is crucial for performance - and the pandemi proves it. Dalam McKinsey \& Company. Diakses dari https://www.mckinsey.com/business-functions/organization/our-insights/hr-saystalent-is-crucial-for-performance-and-the-pandemi-proves-it\#

Hayes, A. F. (2018). Introduction to mediation, moderation, and conditional process analysis: A regression-based approach (Edisi kedua). Diakses dari http://library.lol/main/D273C8C71C1AE4B604733B48DDFE3EC2

Hernaus, T., Maric, M., \& Černe, M. (2019). Age-sensitive job design antecedents of innovative work behavior: The role of cognitive job demands. Journal of Managerial Psychology, 34(5), 368-382. https://doi.org/10.1108/JMP-10-2018-0478

Hsiao, H.-C., Chang, J.-C., Tu, Y.-L., \& Chen, S.-C. (2011). The impact of self-efficacy on innovative work behaviorfor teachers. International Journal of Social Science and Humanity, 1(1), 31-36. https://doi.org/10.7763/ijssh.2011.v1.6

Janssen, O. (2000). Job demands, perceptions of effort-reward fairness and innovative work behaviour. Journal of Occupational and Organizational Psychology, 73(3), 287302. https://doi.org/10.1348/096317900167038

Janssen, O., Van De Vliert, E., \& West, M. (2004). The bright and dark sides of individual and group innovation: A Special Issue introduction. Journal of Organizational Behavior, 25(2), 129-145. https://doi.org/10.1002/job.242

Kaplan, R. M., \& Saccuzzo, D. P. (2013). Psychological testing: Principles, applications \& issues (Edisi kedelapan). Wadsworth Cengage Learning.

Kumar, R. R. (2011). Turn over issues in the textile industry in Ethiopia: A case of ArbaMinch textile company. African Journal of Marketing Management, 3(2), 32-44. Diakses dari https://academicjournals.org/journal/AJMM/article-full-textpdf/05F3E874505

Kyndt, E., \& Baert, H. (2013). Antecedents of employees' involvement in work-related learning: A systematic review. In Review of Educational Research (Vol. 83). https://doi.org/10.3102/0034654313478021

Lecat, A., Beausaert, S., \& Raemdonck, I. (2018). On the relation between teachers' (in)formal learning and innovative working behavior: the mediating role of employability. Vocations and Learning, 11(3), 529-554. https://doi.org/10.1007/s12186-018-9199-x

London, M. (2011). Lifelong learning: Introduction. Dalam P. E. Nathan \& S. W. J. Kozlowski (Eds.), Oxford Library of Psychology (hal. 3-11). https://doi.org/10.1093/oxfordhb/9780195390483.001.0001 
Messmann, G., \& Mulder, R. H. (2011). Innovative work behaviour in vocational colleges: Understanding how and why innovations are developed. Vocations and Learning, 4(1), 63-84. https://doi.org/10.1007/s12186-010-9049-y

Nunnally, J. C., \& Bernstein, I. H. (1994). Psychometric theory (Edisi ketiga). Diakses dari http://library.lol/main/81BC7485BC968C17EA4672B6423B4ED9

Olsen, D. S. (2016). Adult learning in innovative organisations. European Journal of Education, 51(2), 210-226. https://doi.org/10.1111/ejed.12170

Organisation for Economic Co-operation and Development. (2020). Global economy faces gravest threat since the crisis as coronavirus spreads. Diakses April 25, 2021, dari Organisation for Economic Co-operation and Development website: https://www.oecd.org/newsroom/global-economy-faces-gravest-threat-since-thecrisis-as-coronavirus-spreads.htm

Østergaard, C. R., Timmermans, B., \& Kristinsson, K. (2011). Does a different view create something new? the effect of employee diversity on innovation. Research Policy, 40(3), 500-509. https://doi.org/10.1016/j.respol.2010.11.004

Robison, J. (2009, February 19). Building engagement in this economic crisis. Gallup.

Schar, M., Gilmartin, S. K., Rieken, B., Brunhaver, S. R., Chen, H. L., \& Sheppard, S. (2017). The making of an innovative engineer: Academic and life experiences that shape engineering task and innovation self-efficacy. ASEE Annual Conference and Exposition, Conference Proceedings, 2017-June. https://doi.org/10.18260/1-2--28986

Schmidt, C. (2000). Helping the sidelined find more job satisfaction. American Psychological Association.

Scott, S. G., \& Bruce, R. A. (1994). Determinants of innovative behavior: A path model of individual innovation in the workplace. The Academy of Management Journal, 37(3), 580-607. https://doi.org/https://doi.org/10.2307/256701

Shanker, R., Bhanugopan, R., van der Heijden, B. I. J. M., \& Farrell, M. (2017). Organizational climate for innovation and organizational performance: The mediating effect of innovative work behavior. Journal of Vocational Behavior, 100, 67-77. https://doi.org/10.1016/j.jvb.2017.02.004

Sitanggang, L. M. S. (2020, August 10). Demi efisiensi di masa pandemi Corona, sejumlah bank memangkas biaya karyawan. Diakses dari https://insight.kontan.co.id/news/demiefisiensi-di-masa-pandemi-corona-sejumlah-bank-memangkas-biaya-karyawan

Sousa, V. D., \& Rojjanasrirat, W. (2011). Translation, adaptation and validation of instruments or scales for use in cross-cultural health care research: A clear and user-friendly guideline. Journal of Evaluation in Clinical Practice, 17(2), 268-274. https://doi.org/10.1111/j.1365-2753.2010.01434.x

Van Der Heijden, B., Boon, J., Van Der Klink, M., \& Meijs, E. (2009). Employability enhancement through formal and informal learning: An empirical study among Dutch non-academic university staff members. International Journal of Training and 
Development, 13(1), 19-37. https://doi.org/10.1111/j.1468-2419.2008.00313.x

Wahyudi, N. A. (2020, March 19). DKI Jakarta provinsi terinovatif di Indonesia. Bisnis.Com. Diakses dari https://jakarta.bisnis.com/read/20201219/77/1333189/dkijakarta-provinsi-terinovatif-di-indonesia

Woods, S. A., Mustafa, M. J., Anderson, N., \& Sayer, B. (2017). Innovative work behavior and personality traits: Examining the moderating effects of organizational tenure. Journal of Managerial Psychology, 29-42. https://doi.org/10.1108/JMP-01-2017-0016 